\title{
The effect of drought stress on yield, leaf gaseous exchange and chlorophyll fluorescence of dry beans (Phaseolus vulgaris L.)
}

\author{
Rudzani Mathobo $^{\mathrm{ab}^{*}}$, Diana Marais ${ }^{\mathrm{a}}$ and Joachim Martin Steyn ${ }^{\mathrm{a}}$ \\ ${ }^{a}$ Department of Plant Production and Soil Science, Faculty of Natural and Agricultural Sciences, University of \\ Pretoria, Private Bag X20, Hatfield, South Africa; \\ ${ }^{b}$ Limpopo Department of Agriculture, Private Bag X9487, Polokwane, South Africa
}

\section{Highlights}

- Drought stress across all stress levels resulted in a reduction in dry matter production, leaf area index, number of seeds per plant, number of pods per plant, seed size and finally grain yield.

- The highest WUE was found in the treatment which was irrigated on fortnightly bases from 36 DAP. The results suggest that drought stress towards the end of the growing season may not cause serious harm in grain yield.

- The results suggest that drought stress can be practiced in dry bean production in areas where there is a challenge of irrigation water with consideration of the growth stage of the crop.

- The results of the study indicate that drought stress effects on photosynthetic rate were highly significant.

- Chlorophyll fluorescence was also affected by drought stress.

\section{ABSTRACT}

Global food production relies on irrigation, especially in low rainfall areas such as South Africa. The study was conducted to determine the effect of drought stress on growth, yield, leaf gaseous exchange and chlorophyll fluorescence parameters of dry bean under field conditions and the after effects of drought stress upon lifting drought stress. A rain shelter field trial was conducted at the Hatfield Experimental Farm of the University of Pretoria, Pretoria, South Africa. Dry bean cultivar DBS 360 was subjected to five levels of moisture stress arranged in a randomized complete block design with six replications. The plants were exposed to the following drought stress levels: the control: Irrigated to field capacity (S1), Withholding irrigation from 36 days after planting (DAP) for 24 days (S2), Withholding irrigation from 49 DAP for 24 days (S3), Withholding irrigation from 73 DAP to the end of the growing season (S4) and irrigated to field capacity on a fortnightly bases for the rest of

*Corresponding author:

Tel: +27 82436 0561; fax: +27 86513 6654; e-mail: rudzanimathobo@gmail.com 
the season from 36 DAP to the end of the growing season (S5).The results revealed that
drought stress reduced dry matter production, leaf area index, number of pods per plant,
number of seeds per plant, hundred seed weight and grain yield. Treatments S1, S4 and S5
produced statistically similar grain yield. Drought stress towards the end of the growing
season may not cause serious harm in grain yield. Drought stress resulted in a reduction in
photosynthetic rate, intercellular carbon dioxide concentration, stomatal conductance and
transpiration. Chlorophyll fluorescence was also affected by drought stress. The highest
WUE was found in the treatment which was irrigated on fortnightly bases from 36 DAP. This
indicates that with appropriate irrigation it is possible to save water without a great yield loss
in dry bean.

\section{INTRODUCTION}

Dry bean is an important protein grain crop in South Africa grown mostly for human consumption. The average dry bean production in South Africa is about 65 thousand tons per annum while the average annual consumption is 129 thousand tons. This implies that the local market is only able to supply $51 \%$ of the local consumption requirements while the balance is met through imports (DAAF, 2012).

Dry bean require a minimum of 400-500mm of rainfall in the growing season (Liebenberg et $a l .$, 2002). In high rainfall regions of South Africa dry bean is produced under dry land and in low rainfall regions of South Africa supplemental irrigation is necessary. Dry bean has been reported to be very sensitive to drought and on the other side water is scarce in South Africa (Liebenberg et al., 2002). The impact of drought stress is determined by the severity of stress and the ability of plants to adapt to this stress (Rosales et al., 2012). Drought stress has a considerable impact on dry bean growth and seed yield although the ranges of reductions are highly variable due to differences in the timing and intensity of the stress imposed and genotype used (Emam et al., 2010).

Most dry bean production in the developing world occurs under conditions of recurring drought stress (Graham and Ranali, 1997). Drought is considered to be one of the main environmental factors that strongly limit growth and yield of plants worldwide (Chaves et al. 2003). Drought stress occurs when available water in the soil is reduced and transpiration continue to loose water without additional water by rain or irrigation. Drought stress is 
characterized by the reduction of water content, diminished leaf water potential and turgor loss, closure of stomata and decrease in cell enlargement and growth (Jaleel et al., 2009). Drought stress is a problem because it limits plant production resulting in lower yields which leads to reduced food prices and high food prices. Water use efficiency (WUE) is one trait important for plant drought response (Edwards et al., 2012). Water use efficiency is defined as the ratio of dry matter production to water use (Hubick et al., 1986).

The introduction of drought stress reduced leaf area, chlorophyll content, dry matter and yield in two common bean cultivars (D81083 and Sayyard) in Iran (Emam et al. 2010) . Post flowering drought stress resulted in a reduction in seed yield, pods per plant and 100 seed weight in small red seeded common bean (Rezene et al. 2013). Drought stress reduced photosynthetic rate due to stomatal conductance, increased $F_{0}$ accompanied by decrease in $F_{m}$ and no change in $\mathrm{F}_{\mathrm{v}} / \mathrm{F}_{\mathrm{m}}$ in the study conducted on beans (Zlatev and Yordanov 2004).

Therefore, the objective of the study was to determine whether the timing of the drought stress in plant development affects yield, leaf gaseous exchange and chlorophyll fluorescence parameters and also to check the possibility of saving water without losing biomass.

\section{Materials and methods}

\subsection{Experimental site and treatments}

A field experiment was conducted inside a rain shelter at the Hatfield Experimental Farm of the University of Pretoria, Pretoria, South Africa (latitude $25^{\circ} 45^{\prime} \mathrm{S}$, longitude $28^{\circ} 16^{\prime} \mathrm{E}$ and an altitude of 1327 m.a.s.l). The experiment was implemented in March 2013. Drought stress was applied through subjecting the dry bean (Phaseolus vulgaris L) cultivar DBS 360 to five levels of moisture stress arranged in a randomized complete block design with six replications. Drought stress treatments were as follows: the control: Irrigated to field capacity on a weekly bases throughout the growing season (S1), Irrigated to field capacity on a weekly bases and withholding irrigation from 36 days after planting (DAP) for 24 days, then irrigated to field capacity to the end of the growing season(S2), Irrigated to field capacity on a weekly bases and withholding irrigation from 49 DAP for 24 days, then irrigated to field capacity to the end of the growing season(S3), Irrigated to field capacity on a weekly bases and withholding irrigation from 73 DAP to the end of the growing season (S4) and Irrigated to field capacity on a weekly bases and Irrigated to field capacity on a fortnightly bases from 36 
DAP (S5). The plots were $2 \times 2.5 \mathrm{~m}^{2}$, and an intra-row spacing of $30 \mathrm{~cm}$ and inter-row spacing of $7.5 \mathrm{~cm}$ were used. The soil was clay loamy. Top dressing was done 28 DAP using lime ammonium nitrate $(\mathrm{LAN}-28 \% \mathrm{~N})$ at the rate of $30 \mathrm{~kg} / \mathrm{ha}$. Weeding was done by hand.

\subsection{Weather data}

Weather data was collected from an automated weather data station close to the experimental site. Daily solar radiation, maximum and minimum relative humidity, maximum and minimum temperatures and wind speed were collected. Soil moisture was monitored using a 503DR CPN hydro probe neutron water meter (Campbell Pacific Nuclear, California). Readings were taken twice a week, at $0.2 \mathrm{~m}$ to a depth of $1.0 \mathrm{~m}$, from access tubes installed in the middle of each plot and positioned between the rows. A drip irrigation system was used for irrigating the trial.

\subsection{Agronomic data}

The effect of drought stress on dry bean growth was monitored through harvesting three plants per plot at 48 DAP, 64 DAP and 92 DAP. The samples were divided into leaves, stem and pods. The leaf area was measured using a LI 3100 belt-driven leaf area meter (Li Cor, Lincoln, Nebraska, USA). Thereafter the samples were oven-dried for 72 hours at $65^{\circ} \mathrm{C}$ to determine dry matter yield (DM). The total above ground dry matter was determined by adding together the dry mass of the leaves, stems and pods. Grain yield and yield components were determined by harvesting $1 \mathrm{~m}^{2}$ at $134 \mathrm{DAP}$, which were the time the trial was terminated. The plants were harvested by hand. The number of plants per plot, number of seed per plant and number of pods per plant were counted and hundred seed mass was measured. The moisture content of the seed was determined by using a multi grain moisture meter (Dickey John, Auburn, Illinois, USA). Shelled seed mass was measured to determine the shelling \%. Yield was expressed at $10 \%$ seed moisture basis.

\subsection{Leaf gas exchange parameters}

The following parameters were measured three times during the growing season: Net photosynthesis, transpiration, stomatal conductance and intercellular carbon dioxide concentration using a portable gas exchange measuring system (Li 6400, Li-Cor, USA). The leaf temperature was $20 \pm 28{ }^{\circ} \mathrm{C}$, PPFD was $1000 \mu \mathrm{molm}^{-2} \mathrm{~s}^{-1}$, relative humidity was $70 \%$ and the ambient $\mathrm{CO}_{2}$ concentration was $400 \mu \mathrm{molmol}^{-1}$. The data was collected from the fully 
expanded matured $3^{\text {rd }}$ leaf on a sunny day between ten and twelve. The measurements were done at 63, 100 and 105 DAP. Chlorophyll content was measured using a portable chlorophyll content meter (CCM-200, Opti- Sciences, USA). The chlorophyll content measurements were done at 48, 53, 61, 77, 80, 89 and 104 DAP.

\subsection{Chlorophyll fluorescence measurements}

Chlorophyll fluorescence was measured using a 6400-40 leaf chamber fluorometer. The measurements were taken from the top most expanded leaf. Minimal fluorescence $\left(\mathrm{F}_{0}\right)$ was measured for 60 minute dark-adapted leaves and maximal fluorescence $\left(F_{m}\right)$ was measured after a $0.8 \mathrm{~s}$ saturation light pulse for the same leaves. Maximal variable fluorescence $\left(\mathrm{F}_{\mathrm{v}}=\mathrm{F}_{\mathrm{m}}-\right.$ $\left.\mathrm{F}_{0}\right)$ and the photochemical efficiency of PSII $\left(\mathrm{F}_{\mathrm{v}} / \mathrm{F}_{\mathrm{m}}\right)$ for dark adapted leaves were calculated. Photochemical (qP) and non-photochemical (qN) quenching parameters were calculated according to Schreiber et al. (1986), using the nomenclature of Van Kooten and Snel (1990).

\subsection{Statistical analysis}

The analysis of variance was performed using General linear models of the Statistical Analysis System software (SAS, 2010). Means were compared using the Tukey's least of significance differences (LSD) test at $5 \%$ probability level.

\section{Results and discussion}

\subsection{Dry matter}

The dry matter partitioning was highly affected by drought stress introduced at 36 DAP at $\mathrm{P} \leq 0.05$ (Figure 1). The treatment $\mathrm{S} 2$ resulted in a reduction of dry matter of leaves, stem and the total of 24, 29 and $26 \%$ respectively compared to S1. The results also revealed that drought stress highly affected dry matter partitioning at 64 DAP (Figure 2). The treatment S5 resulted in the highest dry matter in terms of leaves, stem and the total. The results revealed that at 64 DAP S1, S2 and S3 resulted in a 6, 15and $18 \%$ reduction in total dry matter partitioning respectively compared to S5. Both S2 and S3 resulted in a significant lower dry matter yield for all the components as compared to S1 and S5. The results further revealed 


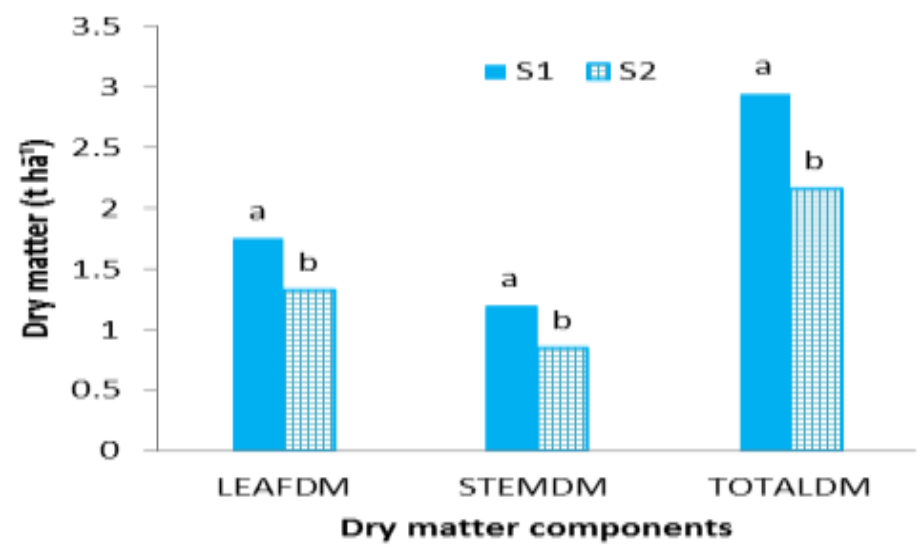

Figure 1 Effect of drought stress on dry matter production of dry bean at 48 DAP Note: Means of bars of the same plant part with the same letter are not significantly different, DAP=Days after planting

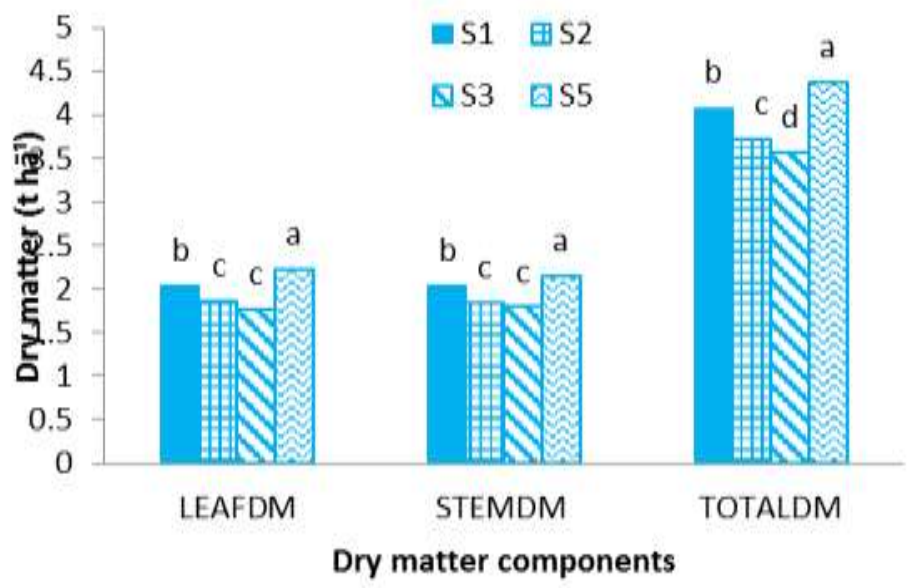

Figure 2 Effect of drought stress on dry matter production of dry bean at 64 DAP

Note: Means of bars of the same plant part with the same letter are not significantly different, DAP=Days after planting 


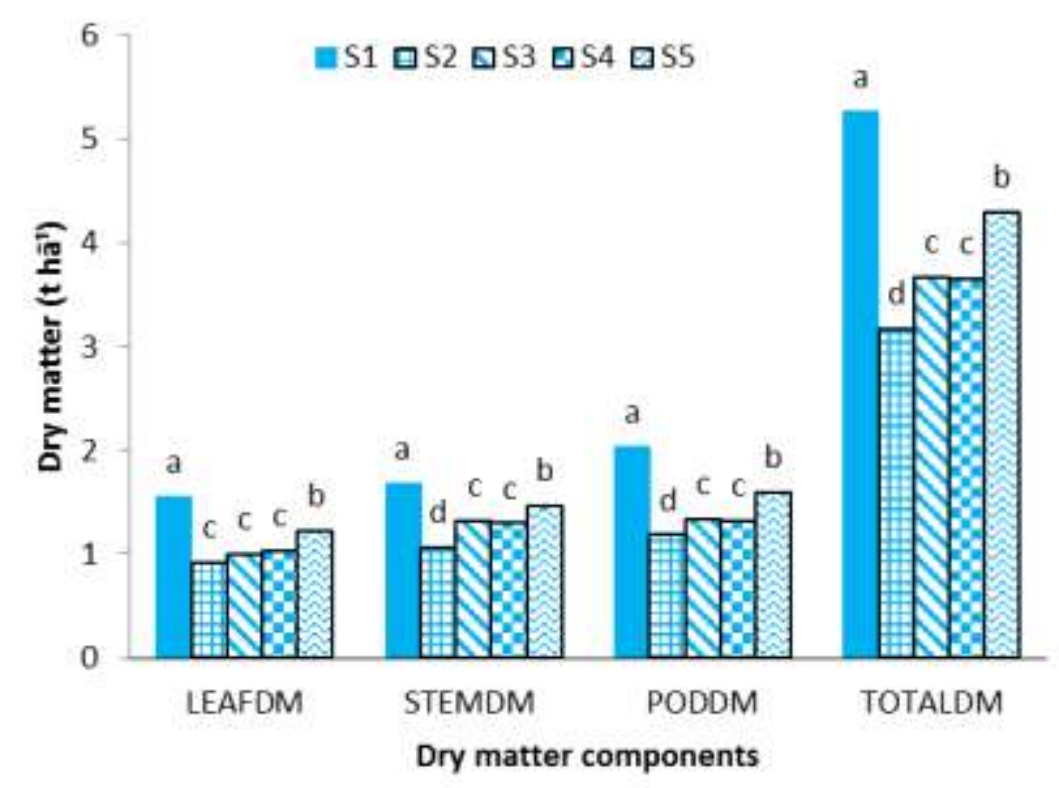

Figure 3 Effect of drought stress on dry matter production of dry bean at 92 DAP

Note: Means of bars of the same plant part with the same letter are not significantly different, DAP=Days after planting

that at 92 DAP dry matter partitioning was still affected by drought stress (Figure 3). The highest dry matter in terms of leaves, stem, pods and total was found in S1 (the well watered or control). The lowest dry matter for each of the components was found in S2. Applying water stress later in the season ( $\mathrm{S} 3$ and $\mathrm{S} 4$ ) also resulted in a significant reduction in the different components as compared to S1 and S5. However, apart from the leaf dry matter yield, it did better than when water stress was applied early in the season (S2). The highest dry matter of leaves and stems was found at 64 DAP and the lowest was found at 95 DAP.

\subsection{Leaf area index}

The results revealed that water stress resulted in a reduction in leaf area index (Table 1). At 48 DAP the leaf area index of S1 treated plants were significantly higher than that of S2 $(\mathrm{P} \leq 0.05)$. At 64 DAP treatment $\mathrm{S} 1$ resulted in the highest LAI compared to the other treatments $\mathrm{P} \leq 0.05$. The treatments $\mathrm{S} 2, \mathrm{~S} 3$ and $\mathrm{S} 5$ resulted in a 21,49 and $20 \%$ reduction of LAI respectively, as compared to S1. At 92 DAP S1 resulted in the highest LAI with S2, S3, $\mathrm{S} 4$, and S5 resulting in 66, 32, 14 and 38\% reduction respectively $(\mathrm{P} \leq 0.05)$. 


\begin{tabular}{|c|c|c|c|}
\hline Stress level & $48 \mathrm{DAP}$ & 64 DAP & 92 DAP \\
\hline $\mathrm{S} 1$ & $2.23 \mathrm{a}$ & $3.13 \mathrm{a}$ & $1.052 \mathrm{a}$ \\
\hline $\mathrm{S} 2$ & $1.96 \mathrm{~b}$ & $2.46 \mathrm{c}$ & $0.361 d$ \\
\hline $\mathrm{S} 3$ & & $1.60 \mathrm{~d}$ & $0.712 \mathrm{c}$ \\
\hline $\mathrm{S} 4$ & & & $0.907 b$ \\
\hline S5 & & $2.68 \mathrm{~b}$ & $0.654 \mathrm{c}$ \\
\hline $\mathrm{Cv} \%$ & 3.85 & 5.05 & 16.29 \\
\hline LSD & $0.119 *$ & $0.153 * *$ & $0.144 * *$ \\
\hline
\end{tabular}

\subsection{Yield and Yield components}

In comparison to the control (S1), the number of pods per plant was significantly reduced by drought stress $(\mathrm{P} \leq 0.01)$ (Table 2). Although S5 resulted in significant less pods than the control, it did lead to a significantly higher number of pods than when plants were stressed in the late reproductive stages (S3 and S4). The number of pods for the S5 plants did, however, not differ significantly from those plants experiencing stress in the early vegetative stage (S2), nor were the differences significant amongst S2, S3 and S4 treated plants. The number of seeds per plant was significantly $(\mathrm{P} \leq 0.05)$ influenced by drought stress (Table 2$)$. The results revealed that $\mathrm{S} 1$ and $\mathrm{S} 5$ treated plants had similar number of seeds per plant and that the number at S5 was similar to S3 and S4 (Table 2). The lowest number of seeds was found at S2. The introduction of drought stress at 36, 49, 73 DAPS and irrigating once in two weeks resulted in a reduction of $22,16,18$ and $10 \%$ respectively compared to S1. The results revealed that the largest seeds were produced by S1 (Table 2) and the smallest was produced by $\mathrm{S} 2$, which is similar to $\mathrm{S} 3$ and $\mathrm{S} 3$ is similar to $\mathrm{S} 4$, which is also similar to S5. The reduction in the hundred seed weight from S1 to S2 was $19.74 \%$. This suggests that introducing drought stress at 36 DAP can results in a serious reduction of seed size. The nonsignificant effect of drought stress for S5 might have resulted from the fact that stress was not so heavy to can disrupt the translocation process of the stresses plants. There was no effect of drought stress on the shelling percentage.

The effect of moisture stress on grain yield was highly significant at $(\mathrm{P} \leq 0.05)$ (Table 2). All the yield parameters were reduced by drought stress which results to the reduction in grain 
yield. There was no significant loss in irrigating the crop once every two weeks (S5) or by introducing water stress late in the reproductive cycle (S4) as compared to the control (S1). The results therefore suggest that stress level S5 and S4 can be adopted without compromising grain yield. The treatment S2 and S3 were significantly affected by moisture stress resulting in the $23-42 \%$ reduction in grain yield as compared to $\mathrm{S} 1$.

Table 2 Effect of drought stress on dry bean yield and yield components of dry beans collected at final harvest (134 DAP)

\begin{tabular}{|c|c|c|c|c|c|c|c|}
\hline $\begin{array}{l}\text { Stress } \\
\text { level }\end{array}$ & $\begin{array}{l}\text { Yield } \\
\left(\mathrm{t} \mathrm{ha}^{-1}\right)\end{array}$ & $\begin{array}{c}\text { Pods plant } \\
1\end{array}$ & $\begin{array}{l}\text { Seeds } \\
\text { plant }^{-1}\end{array}$ & $\begin{array}{l}\text { Hundred seeds } \\
\text { weight }\end{array}$ & $\begin{array}{c}\text { Shelling } \\
\%\end{array}$ & Water use (mm) & $\begin{array}{c}\text { WUE }\left(\mathrm{kg} \mathrm{ha}^{-1}\right. \\
\left.\mathrm{mm}^{-1}\right)\end{array}$ \\
\hline $\mathrm{S} 1$ & $3.20 \mathrm{a}$ & $10.45 \mathrm{a}$ & $36.43 \mathrm{a}$ & $39.03 \mathrm{a}$ & 78 & $420.65 a$ & $7.61 b$ \\
\hline $\mathrm{S} 2$ & $2.48 \mathrm{~b}$ & $8.63 b c$ & $28.31 \mathrm{c}$ & $31.57 \mathrm{~d}$ & 77 & $275.95 d$ & $9.00 \mathrm{~b}$ \\
\hline $\mathrm{S} 3$ & $1.84 \mathrm{c}$ & $8.35 \mathrm{c}$ & $30.58 b c$ & $32.81 \mathrm{~cd}$ & 64 & $382.48 b$ & $4.83 c$ \\
\hline $\mathrm{S} 4$ & $2.89 \mathrm{ab}$ & $8.41 \mathrm{c}$ & $29.91 b c$ & $35.21 b c$ & 79 & $330.36 \mathrm{c}$ & $8.73 b$ \\
\hline S5 & $3.04 \mathrm{a}$ & $9.43 b$ & $32.75 \mathrm{ab}$ & $37.43 \mathrm{ab}$ & 77 & $251.38 \mathrm{e}$ & $12.11 \mathrm{a}$ \\
\hline $\mathrm{Cv} \%$ & 14.88 & 8.37 & 9.82 & 7.34 & 16.94 & 3.69 & 14.87 \\
\hline LSD & $0.48 * *$ & $0.913 * *$ & $3.73 *$ & $3.11 *$ & ns & $14.77 * * *$ & $1.516 * * *$ \\
\hline
\end{tabular}

Note: Means for values in a column with the same letter are not significantly different, DAP: Days after planting, *: significant at $p \leq 0.05$, **: significant at $p \leq 0.01$, ***: significant at $p \leq 0.001$.

\subsection{Water use efficiency}

The effect of drought stress on water use was highly significant at $\mathrm{P} \leq 0.05$ (Table 2) The results revealed that the highest amount of water $(420.65 \mathrm{~mm})$ was used by treatment $\mathrm{S} 1$ and the lowest amount of $251.38 \mathrm{~mm}$ by $\mathrm{S} 5$. The results further indicated that the effect of drought stress on WUE was highly significant at $\mathrm{P} \leq 0.05$. The highest WUE was obtained by S5 (12.11 kg ha $\left.{ }^{-1} \mathrm{~mm}^{-1}\right)$ followed by S2 $\left(8.98 \mathrm{~kg} \mathrm{ha}^{-1} \mathrm{~mm}^{-1}\right), \mathrm{S} 4\left(8.74 \mathrm{~kg} \mathrm{ha}^{-1} \mathrm{~mm}-1\right), \mathrm{S} 1$ (7.61 kg $\mathrm{ha}^{-1} \mathrm{~mm}^{-1}$ ) and finally $\mathrm{S} 3\left(4.81 \mathrm{~kg} \mathrm{ha}^{-1} \mathrm{~mm}^{-1}\right)$ (Table 2). The treatment $\mathrm{S} 3$ resulted in significantly the lowest WUE. 


\subsection{Chlorophyll content}

The effect of drought stress on chlorophyll content was significantly high across all the stressed treatments. S2 was the most affected treatment in all days except at 77 and 104 DAP, resulting in between 11 and 39\% reduction in chlorophyll content. The results indicated that the maximum chlorophyll content was found at 80 DAP from there it started declining. The results also suggest that treatment S2 fail to recover after re-watering (Table 3) on day 61 DAP.

Table 3 Effect of drought stress on chlorophyll content of dry beans

\begin{tabular}{cccccccc}
\hline Treatment & 48 DAP & 53 DAP & 61 DAP & 77 DAP & 80 DAP & 89 DAP & 104 DAP \\
\hline S1 & $12.02 \mathrm{a}$ & $11.00 \mathrm{a}$ & $17.22 \mathrm{a}$ & $20.66 \mathrm{a}$ & $24.29 \mathrm{a}$ & $23.21 \mathrm{a}$ & $20.34 \mathrm{a}$ \\
$\mathrm{S} 2$ & $10.51 \mathrm{~b}$ & $9.81 \mathrm{~b}$ & $14.19 \mathrm{c}$ & $15.17 \mathrm{c}$ & $19.46 \mathrm{c}$ & $14.13 \mathrm{c}$ & $13.58 \mathrm{~cd}$ \\
$\mathrm{~S} 3$ & - & - & $15.90 \mathrm{~b}$ & $14.42 \mathrm{~d}$ & $20.11 \mathrm{bc}$ & $15.02 \mathrm{c}$ & $13.25 \mathrm{~d}$ \\
$\mathrm{~S} 4$ & - & - & & - & - & $17.41 \mathrm{~b}$ & $13.94 \mathrm{c}$ \\
$\mathrm{S} 5$ & - & - & $15.68 \mathrm{~b}$ & $16.96 \mathrm{~b}$ & $20.67 \mathrm{~b}$ & $18.33 \mathrm{~b}$ & $15.17 \mathrm{~b}$ \\
\hline $\mathrm{Cv} \%$ & 2.11 & 3.77 & 3.91 & 3.52 & 4.29 & 5.73 & 3.41 \\
$\mathrm{LSD}$ & $0.35^{* *}$ & $0.69^{*}$ & $0.98^{* *}$ & $0.72^{* *}$ & $1.11^{* *}$ & $1.21 * *$ & $0.62^{* *}$ \\
\hline
\end{tabular}

Note: Means in a column with the same letter are not significantly different, DAP: Days after planting, $C v$ : coefficient of variation, *: significant at $p \leq 0.01$, **: significant at $p \leq 0.001$

\subsection{Photosynthesis $\left(P_{n}\right)$}

The introduction of drought stress had a significant effect on photosynthesis at all three measurement days $(\mathrm{P} \leq 0.01)$ (Table 4). The highest photosynthetic rates were found in $\mathrm{S} 1$ (63 DAP) and the lowest in S3 and S4 (both at 100 and 105 DAP). These results suggest that drought stress during any growth stage of dry bean can results in serious reduction of photosynthetic rates. The reduction can be as high as $45 \%$ with treatment $\mathrm{S} 3$ being the most affected. 
Table 4 Effect of drought stress on dry bean photosynthesis rate, intercellular carbon dioxide concentration, stomatal conductance and transpiration $\left(\mu\right.$ molm $\left.{ }^{-2} \mathrm{~s}^{-1}\right)$

\begin{tabular}{|c|c|c|c|c|c|c|c|c|c|c|c|c|}
\hline \multirow[b]{2}{*}{ Treatment } & \multicolumn{3}{|c|}{ Photosynthesis } & \multicolumn{3}{|c|}{$\begin{array}{l}\text { Intercellular carbon dioxide } \\
\text { concentration }\end{array}$} & \multicolumn{3}{|c|}{ Stomatal conductance } & \multicolumn{3}{|c|}{ Transpiration } \\
\hline & 63 DAP & $100 \mathrm{DAP}$ & $\begin{array}{l}105 \\
\text { DAP }\end{array}$ & $63 \mathrm{DAP}$ & $\begin{array}{l}100 \\
\text { DAP }\end{array}$ & $\begin{array}{l}105 \\
\text { DAP }\end{array}$ & 63 DAP & $\begin{array}{l}100 \\
\text { DAP }\end{array}$ & $\begin{array}{l}105 \\
\text { DAP }\end{array}$ & 63 DAP & $100 \mathrm{DAP}$ & 105 DAP \\
\hline $\mathrm{S} 1$ & $22.92 \mathrm{a}$ & $9.89 a$ & $12.62 \mathrm{a}$ & $286 a$ & $312 c$ & $249 b$ & $0.55 \mathrm{a}$ & $0.32 \mathrm{ab}$ & $0.18 \mathrm{a}$ & $5.87 \mathrm{a}$ & $3.33 a$ & $2.97 \mathrm{ab}$ \\
\hline S2 & $15.40 \mathrm{~d}$ & $7.14 b c$ & - & $259 b$ & $339 \mathrm{ab}$ & - & $0.29 \mathrm{c}$ & $0.36 \mathrm{a}$ & - & $3.86 \mathrm{c}$ & $2.87 \mathrm{a}$ & - \\
\hline S3 & $17.44 \mathrm{c}$ & $5.36 \mathrm{~d}$ & - & $288 \mathrm{a}$ & $355 \mathrm{a}$ & - & $0.39 b$ & $0.36 \mathrm{a}$ & - & $4.70 b$ & $3.01 \mathrm{a}$ & - \\
\hline S4 & - & $6.93 \mathrm{~cd}$ & $8.88 \mathrm{c}$ & - & $331 b c$ & $259 \mathrm{ab}$ & - & $0.32 \mathrm{ab}$ & $0.13 b$ & - & $2.32 b$ & $2.65 b$ \\
\hline S5 & $21.26 b$ & $8.68 \mathrm{ab}$ & $10.50 \mathrm{~b}$ & $282 \mathrm{a}$ & $318 \mathrm{bc}$ & $265 \mathrm{ab}$ & $0.47 \mathrm{ab}$ & $0.29 b$ & $0.16 \mathrm{a}$ & $5.21 b$ & $3.05 \mathrm{a}$ & $3.21 \mathrm{a}$ \\
\hline $\mathrm{Cv} \%$ & 6.50 & 18.6 & 4.01 & 4.09 & 5.61 & 3.22 & 18.84 & 11.00 & 15.40 & 13.00 & 13.93 & 10.04 \\
\hline LSD & $1.54 * *$ & $1.70^{*}$ & $0.55^{* *}$ & $14.05 * *$ & $22.38 * *$ & $10.70^{*}$ & $0.09 * *$ & $0.04 *$ & $0.03 *$ & $0.78 * *$ & $0.49^{* *}$ & $0.38^{*}$ \\
\hline
\end{tabular}




\subsection{Intercellular carbon dioxide concentration ( $\mathrm{Ci})$}

The introduction of drought stress had a significant effect on intercellular carbon dioxide concentration ( $\mathrm{Ci})(\mathrm{P} \leq 0.01)$ (Table 4). The results indicated that at 63 DAP drought stress reduced Ci with S2 resulting in the lowest of $259.31 \mu \mathrm{mol} \mathrm{mol}^{-1}$. At $100 \mathrm{DAP}$ S3 resulted in the highest $\mathrm{Ci}$ of $355.51 \mu \mathrm{mol} \mathrm{mol}{ }^{-1}$ and the lowest at $\mathrm{S} 1$. The results further indicates that at 100 DAP S3 and S2 had statistically similar Ci. At 105 DAP Ci was increased by drought

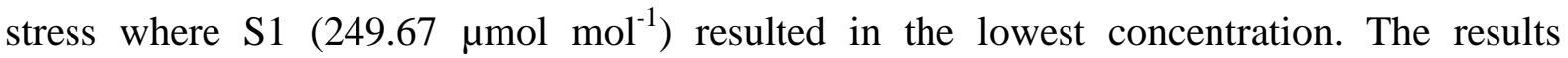
revealed that that severe drought stress increases $\mathrm{Ci}$ and mild drought stress reduces it.

\subsection{Stomatal conductance $\left(g_{s}\right)$}

The stomatal conductance at 63,100 and 105 DAP $(P \leq 0.05)$, was significantly affected by drought stress (Table 4). The results indicated that $\mathrm{g}_{\mathrm{s}}$ was reduced by drought stress with $\mathrm{S} 2$ resulting in $0.287 \mathrm{mmol} \mathrm{m}^{-2} \mathrm{~s}^{-1}$. This was a $48 \%$ reduction as compared to S1. At 100 DAP $\mathrm{S} 3$ and $\mathrm{S} 2$ had the highest value of $\mathrm{g}_{\mathrm{s}}\left(0.362 \mathrm{mmol} \mathrm{m}^{-2} \mathrm{~s}^{-1}\right)$ which was not significantly different from S1 and S4. The treatment S5 had the lowest $g_{s}$ of $0.293 \mathrm{mmol} \mathrm{m}^{-2} \mathrm{~s}^{-1}$ at 100 DAP indicating that the plants in S5 were the most drought stressed at this time. The highest $\mathrm{g}_{\mathrm{s}}$ was observed when the plant was still small and reduced as the plant grows. This is in agreement with previous results observedin mung bean (Uprety and Bhatis, 1989). At 63 and 105 DAP there was a very strong relationship $\left(r^{2}=0.956, r^{2}=0.940\right)$ between photosynthetic rates and stomatal conductance, while at 100 DAP it was weak $\left(r^{2}=0.480\right)$.

\subsection{Transpiration}

The results revealed that at 63 DAP drought stress reduced transpiration rate $(\mathrm{P} \leq 0.001)$ by $34 \%$ for S2 (Table 4). The treatment S1 resulted in the highest transpiration rate. The treatment S3 and S5 were statistically the same. At 100 DAP drought stress reduced transpiration rates $(\mathrm{P} \leq 0.01)$ by $30 \%$ at $\mathrm{S} 4$. The treatments $\mathrm{S} 1, \mathrm{~S} 2, \mathrm{~S} 3$ and $\mathrm{S} 5$ were statistically the same. At 105 DAP the transpiration of S5 was not significantly different to S1 but significantly different from S4. At 63 DAP the stomatal closure was the most prominent determinant for the increased transpiration efficiency $\left(r^{2}=0.999\right)$. The positive correlation between transpiration and stomatal conductance suggests that the reduction of transpiration at S2 was due to stomatal closure. At 100 and 105 DAP there were weak relationship between 
transpiration and stomatal conductance with $\mathrm{r}^{2}=0.007$ and $\mathrm{r}^{2}=0.481$ respectively. The results also revealed that at 63 DAP there was a strong correlation between transpiration and photosynthesis $\left(\mathrm{r}^{2}=0.951\right)$. At 100 and 105 DAP there were weak relationship between transpiration and photosynthesis with $r^{2}=0.256$ and $r^{2}=0.247$ respectively.

\subsection{Minimal chlorophyll fluorescence $\left(F_{0}\right)$}

The effect of drought stress on $\mathrm{F}_{0}$ was significant during 52, 93 and 100 DAP $(\mathrm{P} \leq 0.01)$ (Table 5). The results revealed that drought stress increased $F_{0}$ at all data collection dates. At 52 DAP S3 resulted in a $13 \%$ increase in $\mathrm{F}_{0}$ and $\mathrm{S} 2$ with $4 \%$ increase compared to $\mathrm{S} 1$. The treatment $\mathrm{S} 3$ resulted in an increased $\mathrm{F}_{0}$ of $5.7 \%$ at 93 DAP. At 100 DAP S4 resulted in a $13 \%$ increase in $\mathrm{F}_{0}$.

\subsection{Maximal chlorophyll fluorescence $\left(F_{m}\right)$}

The effect of drought stress was significant at 52 DAP, 93 DAP and 100 DAP (P $\leq 0.05)$ (Table 5). At 52 DAP S5 and S2 resulted in a 4.3 and $27 \%$ increase in $\mathrm{F}_{\mathrm{m}}$ respectively as compared to the control, but S3 resulted in a 25\% reduction. At 93 DAP S3 resulted in a 29 $\%$ reduction in $\mathrm{F}_{\mathrm{m}}$ while $\mathrm{S} 1, \mathrm{~S} 2, \mathrm{~S} 4$ and $\mathrm{S} 5$ were statistically similar. At 100 DAP drought stress resulted in an 11, 28, 31 and $33 \%$ reduction at S4, S2, S3 and S5 respectively. At both dates $\mathrm{S} 3$ resulted in a serious reduction of $\mathrm{F}_{\mathrm{m}}$. Throughout all the data collection dates $\mathrm{S} 3$ fail to recover from water stress.

\subsection{Maximum quantum efficiency of PSII photochemistry $\left(F_{v} / F_{m}\right)$}

This parameter is widely considered to be a sensitive indication of plant photosynthetic performance (Kalaji \& Guo, 2008). Drought stress might result in a decrease in Fv/Fm, but other factors might be involved also. For example the lowest Fv/Fm value after 52 DAP is found in S3, which only just started the drought stress period three days earlier and therefore most likely was not water stressed at 52 DAP. Plants in S2 and S5 were not affected at all (no decrease in Fv/Fm) even though they had been drought stressed for 16 days at 52 DAP. . 
Table 5 Effect of drought stress on minimal chlorophyll fluorescence $\left(\mathrm{F}_{0}\right)$, maximal chlorophyll fluorescence $\left(\mathrm{F}_{\mathrm{m}}\right)$ and maximum quantum efficiency of PSII photochemistry $\left(\mathrm{F}_{\mathrm{v}} / \mathrm{F}_{\mathrm{m}}\right)$ of dry bean

\begin{tabular}{|c|c|c|c|c|c|c|c|c|c|}
\hline \multirow[b]{2}{*}{ Treatment } & \multicolumn{3}{|c|}{$\mathrm{F}_{0}$} & \multicolumn{3}{|c|}{$\mathrm{F}_{\mathrm{m}}$} & \multicolumn{3}{|c|}{$\mathrm{F}_{\mathrm{v}} / \mathrm{F}_{\mathrm{m}}$} \\
\hline & $52 \mathrm{DAP}$ & 93 DAP & 100 DAP & $52 \mathrm{DAP}$ & 93 DAP & $100 \mathrm{DAP}$ & $52 \mathrm{DAP}$ & 93 DAP & $100 \mathrm{DAP}$ \\
\hline $\mathrm{S} 1$ & $157.48 \mathrm{c}$ & $164.15 b$ & $139.74 d$ & $516.87 \mathrm{c}$ & $545.38 \mathrm{a}$ & $537.64 a$ & $0.69 \mathrm{a}$ & $0.69 a$ & $0.73 a$ \\
\hline $\mathrm{S} 2$ & $164.17 b$ & $164.17 b$ & $145.20 \mathrm{c}$ & $539.27 \mathrm{~b}$ & $539.27 \mathrm{a}$ & $386.80 \mathrm{c}$ & $0.69 a$ & $0.69 a$ & $0.62 b c$ \\
\hline S3 & $177.77 \mathrm{a}$ & $173.55 \mathrm{a}$ & $152.68 b$ & $386.18 d$ & $496.30 \mathrm{a}$ & $367.46 \mathrm{~d}$ & $0.53 b$ & $0.51 \mathrm{c}$ & $0.58 \mathrm{c}$ \\
\hline S4 & - & $160.53 b$ & $158.69 \mathrm{a}$ & - & $388.19 b$ & $474.88 b$ & - & $0.63 b$ & $0.66 b$ \\
\hline S5 & $159.29 \mathrm{c}$ & $163.42 b$ & $141.64 \mathrm{~cd}$ & $636.52 \mathrm{a}$ & $521.11 \mathrm{a}$ & $355.39 \mathrm{e}$ & $0.72 \mathrm{a}$ & $0.64 b$ & $0.60 \mathrm{c}$ \\
\hline $\mathrm{Cv} \%$ & 1.44 & 2.68 & 1.76 & 1.77 & 10.70 & 0.51 & 7.08 & 2.47 & 5.93 \\
\hline LSD & $3.81 * *$ & $6.82 *$ & $4.01 * *$ & $14.93 * *$ & $82.12 * *$ & $3.33 * *$ & $0.074 * *$ & $0.02 * *$ & $0.06 * *$ \\
\hline
\end{tabular}

Note: Means in a column with the same letter are not significantly different, DAP = Days after planting, Cv= coefficient of variation, $* *:$ significant at $p=0.01, *$. significant at $p \leq 0.05$ 
The results revealed that drought stress resulted in a reduction in Fv/Fm ratio during 93 and 100 DAPs (Figure 10). Liu et al. (2012) also observed a decline in $F_{v} / F_{m}$ ratio in drought stressed plants of two maize cultivars.

\subsection{Coefficient of photochemical quenching (qP)}

Coefficient of photochemical quenching is an indication of the proportion of open PSII reaction centers, and translates light quantum energy into chemical energy process, which reflects the photosynthetic efficiency and the light use situation of plant (Liu et al., 2012). At 93 DAP there was no significant difference among treatments. At 100 DAP the effects of drought stress are significant with S3 resulting in the lowest which was not significantly different to S2 and S4. The results revealed that at 100 DAP there was no significant difference between S1 and S4 and S5 (Table 6), S4 was still going through drought stress.

Table 6 Effect of drought stress on coefficient of photochemical quenching (qP) and coefficient of nonphotochemical quenching (qN)

\begin{tabular}{|c|c|c|c|c|}
\hline & \multicolumn{2}{|c|}{$\mathrm{qP}$} & \multicolumn{2}{|l|}{$\mathrm{qN}$} \\
\hline Treatment & 93 DAP & 100DAP & 93 DAP & 100DAP \\
\hline $\mathrm{S} 1$ & $0.995 \mathrm{a}$ & $1.014 \mathrm{ab}$ & $0.235 c$ & $3.795 a$ \\
\hline $\mathrm{S} 2$ & $0.994 \mathrm{a}$ & $0.990 \mathrm{bc}$ & $0.303 b$ & $2.402 \mathrm{~cd}$ \\
\hline $\mathrm{S} 3$ & $0.956 \mathrm{a}$ & $0.985 \mathrm{c}$ & $0.379 \mathrm{a}$ & $2.209 d$ \\
\hline S4 & $0.993 \mathrm{a}$ & $1.007 \mathrm{abc}$ & $0.349 \mathrm{a}$ & $3.438 \mathrm{ab}$ \\
\hline S5 & & $1.020 \mathrm{a}$ & & $2.870 \mathrm{bc}$ \\
\hline $\mathrm{Cv}$ & 2.46 & 1.33 & 6.42 & 14.51 \\
\hline LSD & ns & $0.02 *$ & $0.032 * *$ & $0.658^{*}$ \\
\hline
\end{tabular}

Note: Means for values in a column with the same letter are not significantly different, DAP=Days after planting, *: significant at $p \leq 0.01, * *$ : significant at $p \leq 0.001$

\subsection{Coefficient of non-photochemical quenching (qN)}

The effect of drought stress on $\mathrm{qN}$ was significant $(\mathrm{P} \leq 0.05)$ (Table 6). At 93 DAP S3 resulted in the highest $\mathrm{qN}$ followed by $\mathrm{S} 4$ which was not statistically different from each 
other. S3 resulted in a $48 \%$ increase in qN compared to S1. At 100 DAP S1 and S4 resulted in the highest and also statistically similar $\mathrm{qN}$ values. The increase in $\mathrm{qN}$ might have been caused by the large proportion of absorbed light energy not being used by plants in the photosynthesis process.

\section{Discussion}

The introduction of drought stress resulted in the significant reduction in dry matter production on all treatment except S5. The reduction in dry matter production suggests that a decline in photosynthesis resulted in the reduction in leaf development and expansion leading to reduced light interception and smaller plants. The reduction of dry matter production at podding stage has been found to be associated with the translocation of photo-assimilates to pods (Fageria and Santos, 2008). Previous reports indicated the reduction of dry matter production due to drought stress in dry bean (Emam et al. 2012) and soybean (GhassemmiGolezani and Lofti 2012).

The reduction in leaf area index might have resulted from drought stress inhibiting the development of new leaves and leaf senescence. The reduction in leaf area index could have been the result of reduced leaf size through the decrease in expansion of individual leaves (Akyeampong, 1986) and the number of leaves through the cessation of development of new leaves (Acosta- Gallegos, 1988) and premature senescence. The acceleration of leaf senescence has been previously associated with drought stress in soybean (Brevedan and Egli, 2003) and in dry beans (Emam et al., 2010).

The reduction of number of pods in this experiment might have resulted from flower senescence and flower abortion due to drought stress. Previous reports indicated that drought stress resulted in the decline of photosynthesis leading to senescence of flowers, preventing flower development and pod filling leading to pod abortion finally reducing the number of pods per plant in chickpea (Fang et al. 2010) and common bean (Emam et al. 2012; Rezene et al. 2013).

The number of seed per plant for treatment S2, S3 and S4 was significantly affected by drought stress. The reduction of number of seeds might have been caused by flower senescence and flower abortion. Previous reports indicated that drought stress resulted in the reduction of seeds per plant in dry beans (Singh 1995) and white bean (Habibi, 2011).When 
moisture stress was introduced during effective flowering stage the reduction is much greater as compared to the well irrigated treatment in dry beans (Miller and Burke, 1983; Rezene et al., 2013) in chickpea (Fang et al., 2010). The number of seeds for S5 was not significantly affected by drought stress and it might be due to the fact that the available water in the soil maintained the crop until the next irrigation. Previous reports confirmed that partial root drying improved fruit quality in grape tree (Dry and Loveys, 1999).

The reduction in hundred seed weight suggests that drought stress accelerated maturity and results in the development of small seeds. Previous reports has reported the reduction of 100 seed weight in field beans (McEwen et al., 1981) and dry bean (Miller and Burke, 1983; Singh, 1995; Gohari, 2013).On the contrary, drought stress resulted in non-significant effect on 100 seed weight in dry bean (Acosta-Gallegos and Shibatha, 1989; Boutraa and Sanders, 2001).

The reduction in grain yield (S2 and S3) is resulting from the reduction of number of pods per plant, number of seeds per plant and hundred seed weight. Previous results indicated the production of lowest grain yield resulting from treatments stressed during flowering and grain filling stages in soybean (Maleki et al., 2013). Several previous studies also reported a reduction in grain yield due to drought stress in soybean, (Brevedan and Egli 2003; Ghassemmi-Golezani and Lofti, 2012), pinto bean (Ghassemmi-Golezani et al., 2010; and in legumes (Faroog et al., 2016). This reduction might be resulting from the fact that beans responds to drought stress by shedding off leaves, flowers and young pods (Adams et al., 1985). The reduction of grain yield due to moisture stress is variable due to differences in the timing and intensity of stress imposed and the genotype used (Frahm et al., 2004). The nonsignificant effect of drought stress on grain yield of S5 is resulting from the fact that there was no significant effect of drought on number of seeds per plant and hundred seeds weight for S5. For S4 the results suggests that drought stress introduced late in the growing season may not cause a significant loss in grain yield.

The highest water use efficiency by S5 might be due to the production of substantial yield with minimum water. Previous results reported the highest water use efficiency when wheat was irrigated after 21 days (Sarkar et al., 1987). The lowest WUE in S3 was due to the lowest grain yield produced by this treatment. Previous results reported higher WUE in drought stressed plant compared to well watered plants in dry beans (De costa and Liyanage,1997;Gohari, 2013; Khonok 2013). Contrasting results were reported indicating 
that the highest WUE was found in irrigated treatments than non- irrigated tomato plants (Begum et al., 2001).

The reduction in chlorophyll content might have resulted from leaves being damaged and turning yellowish due to drought stress. A decrease in chlorophyll content due to drought stress has been reported in wheat (Talebi, 2011), pea (Inaki-Iturbe et al., 1998), maize (Mohammadkhani and Heidari, 2007), chickpea (Mafakheri et al., 2010), soybean (Makbul et al., 2011) and rice (Chutia \& Borah, 2012). The damage to leaf pigments as a result of water deficit has been reported in acacia (Montagu and Woo, 1999). The decrease in chlorophyll content is resulting from the damage to the chloroplasts caused by active oxygen species (Smirnoff, 1995). Drought stress leads to the production of reactive oxygen species (ROS) such as $\mathrm{O}_{2^{-}}$and $\mathrm{H}_{2} \mathrm{O}_{2}$, which lead to chlorophyll destruction (Mirnoff, 1993; Foyer et al., 1994).

The reduction in photosynthetic rates resulted from stomatal and non-stomatal factors. The reduction of photosynthesis due to drought stress has been reported in faba bean (Girma and Haile, 2014), in grain legumes (Faroog et al. 2016) and dry bean (Lanna et al., 2016). During drought stress water deficit inside the plant tissue develops, leading to a significant inhibition of photosynthesis. A reduction in bean photosynthetic rates due to stomatal closure has been reported (Sharkey and Seemann, 1989). Tang et al. (2002) argued that a combination of stomatal and non-stomatal effects on photosynthesis exists, depending on the extent of drought stress (Yu et al. 2009). Tezara et al. (1999) concluded that water stress inhibits photosynthesis through diminished ribulose-1, 5-bisphosphate (RuBP) supply caused by low ATP synthesis. Considering the biochemical reactions, water deficit can also increase the oxygenase activity of the RuBP carboxylase/oxygenase (Rubisco), reducing carboxylation efficiency. Therefore, decreases in the rate of photosynthesis in drought-stressed plants can be caused by stomatal closure (i.e. reduction of $\mathrm{CO} 2$ availability) and/or impairments in photochemical (i.e. decrease in NADPH and ATP supply) and/or biochemical (i.e. reduced RuBP regeneration and carboxylation efficiency) reactions (Tezera et al. 1999).

The results revealed that mild stress reduced $\mathrm{Ci}$ and severe stress increased it. When $\mathrm{Ci}$ increases it suggests the predominance of non-stomatal limitation to photosynthesis. Previous report indicated that severe water stress increases $\mathrm{Ci}$ and mild water stress decreases $\mathrm{Ci}$ (Lawlor, 1995). The decrease in $\mathrm{Ci}$ indicates the stomatal limitations dominated, with moderate drought stress (Flexas \& Medrano, 2002). 
The reduction in $\mathrm{g}_{\mathrm{s}}$ might have resulted from the stomatal closure which prevent $\mathrm{CO}_{2}$ from entering the leaf and phosynthetic carbon assimilation is decreased in favour of photorespiration. That drought can cause a decrease in $\mathrm{g}_{\mathrm{s}}$ is in agreement with previous results where a $70 \%$ reduction of gs after 22 days of drought stress was observed in dry bean (Rosales et al. 2012). The strong relationship between $P_{n}$ and $g_{s}$ indicates that the reduction in $\mathrm{P}_{\mathrm{n}}$ was regulated mostly by stomatal closure and weak relationship indicates that the reduction in $\mathrm{P}_{\mathrm{n}}$ was regulated by non-stomatal factors (Siddique et al., 1999). The decrease in transpiration due to drought stress is in agreement with previous reports observed in Eucalyptus globulus clones (Osorio et al. 1998), wheat (Yordanov et al. 2001) and dry bean (Aroca et al. 2006).

An increase in $F_{0}$ due to drought stress is in agreement with previous report observed in bean (Zlatev and Yordanov, 2004) and in cattail (Li et al., 2004). An increased $\mathrm{F}_{0}$ is a characteristic of PSII inactivation (Baker and Horton, 1987). The increased $\mathrm{F}_{0}$ might have resulted from the reduced plastoquinone acceptor $\left(\mathrm{Q}_{\mathrm{A}}^{-}\right)$, unable to be oxidized completely because of the electron flow retardation through PSII (Velikova et al., 1999). Even after termination of drought stress the $F_{0}$ values were higher than for the control (e.g S3 at 93 DAP) which suggests that recovery was taking place slowly. The decrease in $\mathrm{F}_{\mathrm{m}}$ due to drought stress is in agreement with previous results observed in bean (Zlatev and Yordanov, 2004). The decrease in $\mathrm{F}_{\mathrm{m}}$ may be related to a decrease in the activity of the water splitting enzyme complex (Aro et al., 1993). Throughout all the data collection dates $\mathrm{S} 3$ fail to recover from water stress. It should be considered that it has been found that measurement of Fv/Fm will only work for severe drought stress measurement in C3 plants due to photorespiration (Flexas et al. 2000). Photorespiration protects desiccating leaves against photo-inhibition not only acting as a sink for equivalents but also preventing over-reduction of the electron carriers between PSII and PSI (Katona et al., 1992).

The results that Fv/Fm for S2 and S5 was not affected by drought is in agreement with previous report observed in cattail and dry beans (Li et al., 2004; Terzi et al., 2010). A decrease in $F_{v} / F_{m}$ indicates down regulation of photosynthesis (Zlatev and Lidon, 2012). Liu et al. (2012) also observed a decline in $F_{v} / F_{m}$ ratio in drought stressed plants of two maize cultivars. The decreases in $\mathrm{F}_{\mathrm{v}} / \mathrm{F}_{\mathrm{m}}$ ratio during 93 DAP for S5 and 100 DAP for S2 suggests that the recovery from water stress is accompanied by structural damage (Schapendonk et al., 1989). This occurrence of chronic photo-inhibition is due to photo-inactivation of PSII centers (Zlatev \& Yordanov, 2004). In bean leaves which has gone through drought, photo- 
inhibitory impact on PSII could occur due to increased light intensity under stress conditions, which usually limits photosynthetic activity (Verhoeven et al., 1997).

The decrease in $\mathrm{qP}$ might have been caused by an increase in the proportion of closed PS II centers (Zlatev and Lidon, 2012). The results for the reduction in $\mathrm{qP}$ due to drought was also observed by previous studies in dry beans (Zlatev and Yordanov, 2004; Terzi et al., 2010).

The increase in $\mathrm{qN}$ might have been caused by the large proportion of absorbed light energy not being used by plants in the photosynthesis process. The increase in $\mathrm{qN}$ due to drought stress is in agreement with previous studies observed in barley, Kalanchoë daigremontiana and dry beans(Vassilev and Manolov 1999; Lu et al., 2003; Zlatev and Yordanov, 2004).

\section{Conclusions}

The introduction of drought stress during effective flowering (S2) and pod filling (S3) stages can result in serous reduction in yield. Drought stress across all stress levels resulted in a reduction in dry matter production, leaf area index, number of seeds per plant, number of pods per plant, seed size and finally grain yield. The highest WUE was found in the treatment which was irrigated on fortnightly bases from 36 DAP. This indicates that with appropriate irrigation it is possible to save water without a great yield loss in this crop. The results suggest that drought stress towards the end of the growing season may not cause serious harm in grain yield. The results suggest that drought stress can be practiced in dry bean production in areas where there is a challenge of irrigation water with consideration of the growth stage of the crop. The results of the study indicate that drought stress effects on photosynthetic rate were highly significant. The reduction was up to $45 \%$. The reduction of photosynthesis at 63 and 105 DAP was greatly due to stomatal conductance. Drought stress resulted in a reduction in intercellular carbon dioxide concentration, stomatal conductance and transpiration. Chlorophyll fluorescence was also affected by drought stress. Drought stress can have serious effects on leaf gaseous exchange rate and chlorophyll fluorescence depending on the growth stage of the plant and the duration of drought stress. 


\section{Acknowledgements}

We would like to thank the Limpopo Department of Agriculture and farm labourers of the University of Pretoria for the invaluable support during this study.

\section{REFERENCES}

Acosta-Gallegos, J.A., 1988. Selection of common bean (Phaseolus vulgaris L.) genotypes with enhanced drought tolerance and biological nitrogen fixation. $\mathrm{PhD}$ thesis. Michigan State University, East Lansing.

Acosta-Gallegos, J.A., Shibata, J.K., 1989. Effect of water stress on growth and yield of indeterminate dry bean (Phaseolus vulgaris L.) cultivars. Field Crop Res., 20, 81-93.

Akyeampong, E., 1986. Some responses of cowpea to drought stress. In: Haque I Jutzi S $\&$ Neate PJH. (Eds), Potentials of forage legumes in farming systems of sub-Saharan Africa - Proceedings of a workshop held at ILCA, Addis Ababa, Ethiopia.

Aro, E.M., Virgin, I., 1993. Photo inhibition of photosystem II. Inactivation, protein damage and turnover. Biochem. Biophys. Acta. 1143(2), 113-134.

Aroca, R., Ferrante, A., Vernieri P. Chrispeels, M.J., 2006. Drought, abscisic acid and transpiration rate effects on the regulation of pip aquaporin gene expression and abundance in Phaseolus vulgaris Plants. Ann. Bot. 98, 1301-1310.

Baker, N.R., Horton, P., 1987. Chlorophyll fluorescence quenching during photoinhibition. In: Kyle, D.J., Osmond, C.B., Amtzen, C.J. (eds). Photo-inhibition. Elsevier, Amsterdam, pp 145-168.

Begum, M.N., Karim, A.J.M.S., Rahman, M.A., and Egashira, K., 2001. Effect of irrigation and application of phosphorus fertilizer on the yield and water use of tomato grown on a clay terrace soil of Bangladesh. J. Fac. Agr. Kyushu U. 45, 611619.

Boutraa, T., Sanders, F.E., 2001. Effects of interactions of moisture regime and nutrient addition on nodulation and carbon partitioning in two cultivars of bean (Phaseolus vulgaris L.). J. Agron. Crop Sci. 186, 229-237.

Brevedan, R.E., Egli, D.B., 2003. Short periods of water stress during seed filling, leaf senescence, and yield of soybean. Crop Sci., 75, 2083-2088.

Chaves, M. M., Maroco, J. P., Pereira, J., 2003. Understanding plant responses to drought from genes to the whole plant. Functional Plant Biol., 30, 239-264. 
Chutia, J., Borah, S.P., 2012. Water Stress Effects on Leaf Growth and Chlorophyll Content but Not the Grain Yield in Traditional Rice (Oryza sativa Linn.) Genotypes of Assam, India II. Protein and proline status in seedlings under peg induced water stress AJPS, 3, 971-980

De costa, W.A.J.M., Liyanage, L.P., 1997. Effects of potassium and water availability on water use efficiency of common beans (Phaseolus vulgaris L.). J. Natl Sci. found., J.Natn.Sci.Foundation Sri Lanka, 25, 241-254.

Edwards, C.E, Ewersa, B.E, McClungd, C.R, Loud, P., Weiniga, C., 2012. Quantitative Variation in Water-Use Efficiency across Water Regimes and Its Relationship with Circadian, Vegetative, Reproductive, and Leaf Gas-Exchange Traits. Mol. Plant. 5,653-668.

Emam, Y., Shekoofa, A., Salehi, F., Jalali, A.H., P., 2010. Water stress effects on two common bean cultivars with contrasting growth habits. Am. Eurasian J. Agric. Environ., 9, 495-499.

Emam, Y., Shekoofa, A., Salehi, F., Jalali, A.H., Pessarakli, M., 2012. Drought stress effects on two common bean cultivars with contrasting growth habits. Arch. Agron. Soil Sci., 58 527-534.

Fageria, N.K., Santos, A.B., 2008. Yield physiology of Dry bean. J. Plant Nutr., 31, 983 $-1004$.

Fang, X., Turner, N.C., Yan, G., Li, F., Siddique, K.H.M., 2010. Flower numbers, pod production, pollen viability, and pistil function are reduced and flower and pod abortion increased in chickpea (Cicer arietinum L.) under terminal drought. J. Exp. Bot. 61, 335-345.

Faroog, M., Gogoi, N., Barthakur, S., Baroowa, B., Bharadwaj, N., Alghamdi, S.S., Siddique K.H.M., 2016. Drought stress in grain legumes during reproduction and grain filling. J. Agro. Crop Sci. 1-23 www.researchgate.net>publication (Accesses on the 02 April 2016)

Flexas, J., Medrano, H., 2002. Drought-inhibition of photosynthesis in $\mathrm{C}_{3}$ plants: Stomatal and non-stomatal limitations revisited. Ann. Bot. 89, 183-189.

Flexas. J., Briantais, J.M., Cerovic, Z., Medrano, H., Moya, I., 2000. Steady-state and maximum chlorophyll fluorescence responses to water stress in grapevine leaves: a new remote sensing system. Remote Sens Environ, 73, 283-297.

Foyer, C.H., Descourvieres, P., Kunert, K.J., 1994. Photo oxidative stress in plants. Plant Physiol., 92, 696-717. 
Frahm, M.A., Rosas, J.C., Mayek-Perez, N., Lopez-Salina, S.E., Acosta-Gallegos, J.A., Kelly J.D., 2004. Breeding beans for resistance to terminal drought in the Lowland tropics. Euphytica, 136, 223-232.

Ghassemmi-Golezani, K., Lotfi, R., 2012. Response of soybean cultivars to water stress at reproductive stages. Intl. J. Pl. An. and Env. Sci., 2, 198-202.

Ghassemmi-Golezani, K., Zafarani-Moattar, P., Raey, Y., Mohammadi, A., 2010.

Response of pinto bean cultivars to water deficit at reproductive stages. J. Food Agric. Environ., 8, 801-804.

Girma, F., Haile, D., 2014. Effects of supplemental irrigation on physiological parameters and yield of faba bean (Vicia faba L.) varieties in the highlands of Bala, Ethiopia. J. Agron., 13, 29-34.

Gohari, A.A., 2013. Effects of water infiltration of soil on yield and water use efficiency of common bean (Phaseolus vulgaris L.). Intl. J. Agron. Plant. Prod. Vol.,Intl. J. of Agron. Plant Prod., 4, 459-463.

Graham, P.H., Ranalli, P., 1997. Common bean (Phaseolus vulgaris L.). Field Crops Res. $53,131-146$.

Habib, G., 2011. Influence of drought on yield and yield components in white bean. World Acad. Sci. Eng. Technol., 55, 244-253.

Hubick, K.T., Farquhar, G.D., Shorter, R., 1986. Correlation between water use efficiency and carbon isotope discrimination in diverse peanut (Arachis) germplasm. Aust. J. Plant Physiol. 13, 803-816.

Inaki-Iturbe, O., Escuredo, P.R., Arrese-Igor, C., Becana, M., 1998. Oxidative damage in pea plants exposed to water deficit or paraquat. Plant. Physiol., 116, 173-181.

Jaleel, C.A., Manivannan, P. Wahid, A., Farooq, M., Somasundaram, R., Panneerselvam, R., 2009. Drought stress in plants: a review on morphological characteristics and pigments composition. Int. J. Agric. Biol., 11,100-105.

Kalaji, H.M., Guo, P., 2008. Chlorophyll fluorescence: a useful tool in barley plant breeding programs. In: Sánchez A. \& Gutierrez, S. J. (Eds.). Photochemistry Research Progress. Nova Science Publishers, Inc.

Khonok, A., 2013. The evaluation of water use efficiency in common bean (Phaseolus vulgaris L.) in irrigation condition and mulch. Sci. Agric., 2, 60-64.

Lanna, A.C., Mitsuzono, S.T., Terra, T.G.R., Vianello, R.P., De Figueiredo Carvalho, M.A., 2016. Physiological characterization of common bean (Phaseolus vulgaris L.) 
genotypes, water stress induced with contrasting response towards drought. AJCS, 10, 1-6.

Lawlor, D.W., 1995. The effects of water deficits on photosynthesis. In: Smirnoff, N., (Ed.). Environment and plant metabolism. Flexibility and acclimation. Oxford, BIOS Scientific publishers.

Li, S., Pezeshki, S.R., Goodwin, S., 2004. Effects of soil moisture regimes on photosynthesis and growth in cattail (Typha latifolia). Acta Oecologica 25, 17-22.

Liebenberg, A.J., Van Wyk, C., Trent, C., Swanepoel, S.C., Mc Donald, A., EIS, I.J., 2002. Dry bean production manual. Agricultural Research Council- Grain Crops Institute. Potchefstroom, South Africa.

Liu, M., Qi, H., Zhang, Z.P., Song, Z.W., Kou, T.J., Zhang, W.J., Yu, J.L. 2012. Response of photosynthesis and chlorophyll fluorescence to drought stress in two maize cultivars. Afr. J. Agric. Res., 34, 4751-4760.

Lopez, F.B., Johansen, C., Chauhan, Y.S., 1996. Effect of timing of drought stress on phenology, yield and yield components of a short-duration pigeon pea. J. Agron. Crop Sci., 177,311-320.

Lu, C., Qiu, N., Lu, Q., Wang, B., Kuang, T., 2003. PSII photochemistry, thermal energy dissipation, and the xanthophyll cycle in Kalanchoë daigremontiana exposed to a combination of water stress and high light. Physiol. Plant., 118, 173-182.

Mafakheri, A., Siosemardeh, A., Bahramnejad, B., Struik, P.C., Sohrabi, Y., 2010. Effect of drought stress on yield, proline and chlorophyll contents in three chickpea cultivars. AJCS, 4, 580-585.

Makbul, S., Saruhan Güller, N., Durmuş, N. Güven, S., 2011. Changes in anatomical and physiological parameters of soybean under drought stress. Turk. J. Bot., 35, 369-377.

Maleki, A., Naderi, A., Naseri, R., Fathi, A., Bahamin, S., Maleki, R., 2013. Physiological Performance of Soybean Cultivars under Drought Stress. BEPLS, 2, $38-44$.

Maxwell, K., Johnson, G.N., 2000. Chlorophyll fluorescence-a practical guide. J. Exp. Bot.51 659-668.

McEwen, J., Bradner, R., Briggs, G.G., Bromilow, R.H., Cockhain, A.J., Day, J.M., Fletcher, K.E., Legg, B.J., Roughely, R.J., Salt, G.A., Simpson, H.R., Webb, R.M., Witly, J.F., Yeoman, D.P., 1981. The effects of irrigation, nitrogen fertilizer and the control of pests and pathogens on spring-sown field beans (Vicia faba L.) and residual effects on two following winter wheat crops. J. Agric. Sci., 96,129-150. 
Medrano, H., Escalona, J.M., Bota, J., Gulias, J., Flexas, J., 2002. Regulation of photosynthesis of $\mathrm{C}_{3}$ plants in response to progressive drought: stomatal conductance as a reference parameter. Ann. Bot., 89, 895-905.

Miller, D.E., Burke, D.W., 1983. Response of dry beans to daily deficit sprinkler irrigation. Agron. J., 75, 775-778.

Mirnoff, N., 1993. The role of active oxygen in the response of plants to water deficit and desiccation. New Phytol., 125, 27-58.

Mohammadkhani, N., Heidari, R., 2007. Effects of water stress on respiration, photosynthetic pigments and water content in two maize cultivars. Pak. J. Biol. Sci., $10,4022-4028$.

Molina, J.C., Moda-Cirino, V., Da, S.F., Junior, N., De Faria, R.T., Destro, D., 2001. Response of common bean cultivars and lines to water stress. Crop Breed Appl. Biotechnol. 1, 363-372.

Montagu, K.D., Woo, K.C., 1999. Recovery of tree photosynthetic capacity from seasonal drought in the wet-dry tropics: The role of phyllode and canopy processes in Acacia auriculiformis. Aust. J. Plant Physiol., 26, 135-145.

Nikolaeva, M.K., Maevskaya, S.N., Shugaev, A.G., Bukhov, N.G., 2010. Effect of drought on chlorophyll content and antioxidant enzyme activities in leaves of three wheat cultivars varying in productivity. Russian J. Plant Physiol., 57, 87-95.

Osorio, J., Osorio, M.L., Chaves, M.M., Pereira, J. S., 1998. Effects of water deficit on ${ }^{13} \mathrm{C}$ discrimination and transpiration efficiency of Eucalyptus globulus clones. Austr. J. Plant Physiol., 25, 645-251.

Rezene, Y., Gebeyehu, S., Zelleke, H., 2013. Morpho-physiological response to postflowering drought stress in small red seeded common bean (Phaseolus vulgaris L.) genotypes. J. Plant stud., 2, 42-53.

Rosales, M.A., Ocampo, E., Rodriguez-Valentin, R., Olvera-Carrillo, Y., AcostaGallegos, J. Covarrubias, A.A., 2012. Physiological analysis of common bean (Phaseolus vulgaris) cultivars uncovers characteristics related to terminal drought. Plant physiol. and Biochem. 56, 24-34.

Sarkar, A.A., Hassan, A.A., Ali, M.I., Chanda, M.C., Basak, B.C., 1987. Effect of fertilizer and irrigation on the yield of wheat at the G.K. project area. Bangladesh J. Nuclear Agric.

$3,66-74$. 
Schapendonk, A. H. C. M., Spitters, C. J. T., Groot, P. J., 1989. Effects of water stress on photosynthesis and chlorophyll fluorescence of five potato cultivars Potato. Res., 32, 17-32.

Schreiber, U., Schliwa, U., Bilger, W., 1986. Continuous recording of photochemical and non-photochemical chlorophyll fluorescence quenching with a new type of modulation fluorometer. Photosynth. Res. 10 51-62.

Sharkey, T.D., (1990) Water stress effects on photosynthesis. Photosynthetica, 24, 651661.

Sharkey, T.D., Seemann, J.R. 1989. Mild water stress effects on carbon-reduction-cycle intermediates, ribulose bisphosphate carboxylase activity, and spatial homogeneity of photosynthesis in intact leaves. Plant Physiol., 89, 1060- 1065.

Siddique, M.R.B., HAMID, A., Islam, M.S., 1999. Drought stress effects on photosynthetic rate and leaf gas exchange of wheat. Bot. Bull. Acad. Sin., 40, 141145.

Singh, S.P. 1995. Selection for water-stress tolerance in interracial populations of common bean. Crop Sci., 35, 118-124.

Smirnoff, N., 1995. Antioxidant systems and plant response to the environment. In:

Smirnoff V (Ed.), Environment and Plant Metabolism: Flexibility and Acclimation, BIOS Scientific Publishers, Oxford, UK.

Stirbet, A., Govindjee, 2011. On the relation between the Kautsky effect (chlorophyll a fluorescence induction) and photosystem II: Basics and applications of the OJIP fluorescence transient. J. Photochem. Photobiol. B: Biol., 104, 236-257.

Taiz, L., Zeiger, E., 2006. Plant Physiology. $4^{\text {th }}$ Ed. Sinauer Associates, Inc., Publishers, Sutherland, Massachusetts, USA. pp125.

Talebi, R., 2011. Evaluation of chlorophyll content and canopy temperature as indicators for drought tolerance in durum wheat (Triticum durum Desf.). Aust. J. of Basic Appl. Sci., 5, 1457-1462.

Tang, A.C., Kawamitsu, Y., Kanechi, M., Boyer, J.S. 2002. Photosynthetic oxygen evolution at low water potential in leaf discs lacking an epidermis. Ann. Bot., 89, 861-870.

Terzi, R., Sağlam, A., Kutlu, N., Nar,H., Kadioğlu, A., 2010. Impact of soil drought stress on photochemical efficiency of photosystem II and antioxidant enzyme activities of Phaseolus vulgaris cultivars. Turk. J. Bot., 34, 1-10 
Tezara, W., Mitchell, V.J., Driscoll, S.D., Lawlor, D.W., 1999. Water stress inhibits plant photosynthesis by decreasing coupling factor and ATP. Nature, 401, 914-917.

Uprety, D.C., Bhatis, R., 1989. Effect of water stress on the photosynthesis, productivity and water status of mung bean (Vigna radiate L. Wilczek) J. Agron. Crop. Sci., 163, 115-123.

Van Kooten, O., Snel, J.F.H., 1990. The use of chlorophyll fluorescence nomenclature in plant stress physiology. Photosynth. Res., 25, 147-150.

Vassilev, A., Manolov, P., 1999. Chlorophyll fluorescence of barley (H. vulgare L.) seedlings grown in excess of Cd. Bulg. J. Plant Physiol., 25, 67-76.

Velikova, V., Tsonev, T., Yordanov, I., 1999. Light and $\mathrm{CO}_{2}$ responses of photosynthesis and chlorophyll fluorescence characteristics in bean plants after simulated acid rain. Physiol. Plant, 107, 77-83.

Verhoeven, A.S., Demmig-Adams, B., Adams, B.B., 1997. Enhanced employment of the xanthophylls cycle and thermal energy dissipation in spinach exposed to high light and N stress. Plant Physiol., 113, 817-824.

Yordanov, I., Tsonev, T., Velikova, V., Georgieva, K., Inanov, P., Tsenov, N., Petrova, T., 2001. Changes in $\mathrm{CO}_{2}$ assimilation, transpiration and stomatal resistance of different wheat cultivars experiencing drought under field conditions. Bulg. J. of Plant Physiol., 27, 20-33.

Yu, D.J., Kim, S.J., Lee, H.J., 2009. Stomatal and non-stomatal limitations to photosynthesis in field-grown grapevine cultivars. Biol. Plant., 53, 133-137.

Zlatev, Z., Lidon, F.C., 2012. An overview on drought induced changes in plant growth, water relations and photosynthesis. Emir. J. Food Agric., 24, 57-72.

Zlatev, Z.S., Yordanov, I.T., 2004. Effects of soil drought on photosynthesis and chlorophyll fluorescence in bean plants. Bulg. J. of Plant Physiol., 30, 3-18. 